\title{
Synthesis of aminopropyl triethoxysilane-functionalized silica and its application in speciation studies of vanadium(IV) and vanadium(V)
}

\author{
Aslı Erdem ${ }^{\mathrm{a}, *}$, Talal Shahwan $^{\mathrm{b}}$, Ali Çağır ${ }^{\mathrm{a}}$, Ahmet E. Eroğlu ${ }^{\mathrm{a}}$ \\ a Department of Chemistry, Izmir Institute of Technology, Urla, 35430 Izmir, Turkey \\ ${ }^{\mathrm{b}}$ Department of Chemistry, Birzeit University, Ramallah, West Bank, Palestine
}

\section{A R T I C L E I N F O}

\section{Article history:}

Received 2 June 2011

Received in revised form 15 August 2011

Accepted 16 August 2011

\section{Keywords:}

Vanadium(IV)

Vanadium(V)

Amine-functionalized silica

Speciation

Inductively coupled plasma mass

spectrometry

\begin{abstract}
A B S T R A C T
A solid phase extraction sorbent, aminopropyl triethoxysilane-functionalized silica was prepared and used for vanadium speciation prior to inductively coupled plasma mass spectrometric determination. The necessary sorption parameters such as sorption $\mathrm{pH}$, reaction temperature, sorbent amount and sample volume were optimized. The sorption for $\mathrm{V}(\mathrm{V})$ and $\mathrm{V}(\mathrm{IV})$ under the optimized conditions was $98 \%( \pm 1)$ and was lower than $10 \%$, respectively. The sorption process was investigated both from a kinetic perspective and also in terms of Freundlich, Dubinin-Radushkevich and Langmuir isotherm models to characterize the uptake of vanadate ion by the functionalized silica. Desorption from the sorbent was realized with $0.5 \mathrm{~mol} \mathrm{~L}^{-1}$ thiourea prepared in $0.2 \mathrm{~mol} \mathrm{~L}^{-1} \mathrm{HCl}$. Among the possible interfering species tested, $\mathrm{Te}(\mathrm{IV})$, $\mathrm{Se}(\mathrm{IV}), \mathrm{Se}(\mathrm{VI})$ and $\mathrm{Fe}(\mathrm{III})$ showed interference effects with $\mathrm{V}(\mathrm{V})$ signal. The validity of the method was first checked via spike recovery experiments with four different types of water; namely ultra pure, bottled drinking, tap, and sea water for different concentrations of $\mathrm{V}(\mathrm{V})$. The percent recovery values changed between 87 and 108 for all water types. The accuracy of the proposed methodology was also checked by analyzing a standard reference material (NIST, SRM 1643e) and a good agreement was found between the determined and the certified value. The proposed methodology has also been shown to be applicable for the separate sorption of $\mathrm{V}(\mathrm{V})$ in the absence/presence of $\mathrm{V}(\mathrm{IV})$ and for the sorption of both $\mathrm{V}(\mathrm{IV})$ and $\mathrm{V}(\mathrm{V})$ in waters. The amount of $\mathrm{V}(\mathrm{IV})$ can then be determined from the difference.
\end{abstract}

(c) 2011 Elsevier B.V. All rights reserved.

\section{Introduction}

Toxic heavy metal pollution in air, soil, and water is a growing global problem that conveys detrimental effects to the environment. There are natural and anthropogenic sources for heavy metal pollution including coal-burning, use of natural gas, paper and several other industries, etc. [1,2]. Depending on the chemical form and exposure level, heavy metals can potentially be very harmful to humans and to the whole biosphere. Thus the detection and quantification of heavy and/or essential metals at relatively highto-trace levels in environmental, biological, geological matrixes have become necessary for better understanding of the global systems [3].

Vanadium is widely distributed in the Earth's crust and has been recognized as a potential pollutant [4,5]. It originates from primary sources such as ores, concentrates, metallurgical slags, and petroleum residues. In addition, it is widely used in the production of special steels, temperature-resistant alloys, pigments and paints. Making up about $0.014 \%$ of the Earth's crust, it is the fifth most

\footnotetext{
* Corresponding author. Tel.: +90 232750 7580; fax: +90 2327507509.

E-mail address: asli.erdem@ege.edu.tr (A. Erdem).
}

abundant transition metal [6]. It is also found at rather high concentrations in some freshwaters and is listed as a metal of concern by the United States Environmental Protection Agency (USEPA) [7].

Vanadium is known as an essential trace element for plants and animals. It has oxidation states from -1 to +5 , and in nature and biological systems, it is most commonly found in the +4 and +5 states as tetravalent vanadyl $\left(\mathrm{VO}^{2+}\right)$ and pentavalent vanadate $\left(\mathrm{HVO}_{4}{ }^{2-}, \mathrm{VO}_{3}{ }^{-}\right.$and/or $\left.\mathrm{H}_{2} \mathrm{VO}_{4}{ }^{-}\right)$species, respectively. A number of monomeric and polymeric tetravalent and pentavalent vanadium species can also be present in aqueous solutions and the composition of each depends upon $\mathrm{pH}$ and species concentrations [8]. In oxidizing media the vanadium ion is present as the hydrated monomer of vanadate $\left(\mathrm{HVO}_{4}{ }^{2-}\right.$ or $\left.\mathrm{H}_{2} \mathrm{VO}_{4}{ }^{-}\right)$at micromolar concentrations near neutral $\mathrm{pH}$, whereas in reducing media, the anion is reduced to vanadyl cation $\left(\mathrm{VO}^{2+}\right)$ within few minutes. If the conditions are strongly reducing, vanadium may also exist as trivalent $[\mathrm{V}(\mathrm{III})]$ and divalent $[\mathrm{V}(\mathrm{II})]$ ions $[9,10]$.

Although vanadium is toxic at high concentrations it is important for biological systems at low concentrations $\left(\mathrm{mg} \mathrm{L}^{-1}\right)$. Indeed, it is essential to cell growth and is known to possess anti-cancer, anti-diabetic, and anti-HIV properties. Although being a nutritional element, vanadium is not accumulated by the plants and animals; the only organisms known to bioaccumulate vanadium to 
a significant degree are mushrooms, tunicates and sea squirts. The occurrence of vanadium in sea squirts is supposed to be one of the main sources of this metal in crude oil and oil shales which is also an indication of the environmental pollution. At $\mathrm{mg} \mathrm{L}^{-1}$ concentration level, vanadium is toxic to plants, mice, freshwater organisms, and humans. Moreover, the $\mathrm{V}(\mathrm{V})$ species is more toxic than the $\mathrm{V}(\mathrm{IV})$ and V(III) oxidation states. Thus, it is important to both separate and quantify the vanadium species in order to assess their potential risk to the environmental systems $[10,11]$.

There are many methods for vanadium determination in various matrices [12-14]. The conventional volumetric [15] and gravimetric [16] methods can also be used. Since vanadium concentrations in natural samples are very low (in the range of $\mu \mathrm{gL}^{-1}$ ) [17] more powerful analytical methods are required for the determination. Only a few of these methods show sufficient sensitivity, such as neutron activation analysis (NAA) [18], electrothermal atomic absorption spectrometry (ETAAS) [19] inductively coupled plasma atomic emission spectrometry (ICP-AES) [20] and inductively coupled plasma mass spectrometry (ICP-MS) [21] as well as some UV-VIS spectrophotometric methods [22,23].

In addition to the determination of total concentration, it is nowadays well recognized that understanding of biogeochemical processes depends upon the knowledge of the chemical forms, or species, that are present in the natural environment. For vanadium, most of the speciation studies are based on the determination of both the total dissolved concentration and the concentration of one of its forms, $\mathrm{V}(\mathrm{IV})$ or $\mathrm{V}(\mathrm{V})$, and then on finding out the concentration of the other form by subtraction. Minelli et al. [19] developed a sensitive method for monitoring and speciation of $V(I V)$ and $V(V)$ in Italian waters at trace levels. A strong anion exchange column loaded with disodium ethylendiaminetetraacetic acid ( $\mathrm{Na}_{2}$ EDTA) was used to trap both vanadium species at $\mathrm{pH}$ 3. The vanadyl ion $\left(\mathrm{VO}^{2+}\right)$ which was selectively eluted by means of an aqueous solution containing $\mathrm{Na}_{2}$ EDTA, tetrabutylammonium hydroxide and isopropanol, was subsequently determined by ETAAS. The concentration of vanadate ion was calculated by subtracting the vanadyl ion concentration from the total concentration. In another study, a flow injection system coupled to ICP-OES was used for on-line preconcentration and subsequent determination of vanadium [24]. Trace amounts of vanadium were preconcentrated at $\mathrm{pH} 7.0$ by sorption on a conical minicolumn packed with immobilized yeast cells in the absence of complexing reagent. Vanadium was removed from the minicolumn with the use of $50 \% \mathrm{HCl}$ solution. A similar study utilizing microcolumns packed with L-methionine immobilized on controlled pore glass (CPG) as solid phase extractant was proposed by Pacheco et al. [25]. At pH 5.0, L-methionine was reported to be selective only towards $\mathrm{V}(\mathrm{V})$ while total vanadium was quantitatively adsorbed by the solid phase at pH 9.0 (as $\mathrm{V}(\mathrm{V})$ ) due to oxidation of $\mathrm{V}(\mathrm{IV})$ in alkali media. Vanadium species retained by L-methionine were quantitatively eluted from the column with $10 \% \mathrm{HCl}$. Effects of acidity, sample flow rate, eluent concentration and interfering ions on the recovery of the analytes have also been investigated.

Amberlite IRA-904 resin modified with tetrakis ( $p$ carboxyphenyl) porphyrin (TCPP) was used to preconcentrate vanadium species [26]. Several parameters, such as sorption capacity of the chelating resin, $\mathrm{pH}$ for retention of $\mathrm{V}(\mathrm{IV})$ and $\mathrm{V}(\mathrm{V})$ and volume of sample and eluent were evaluated. Both vanadium species sorbed on TCPP-modified resin were eluted with the use of $2.0 \mathrm{~mol} \mathrm{~L}^{-1}$ nitric acid and determined by AAS. For speciation studies, CDTA was added to the sample for complexing V(IV) which was not retained on the microcolumn. The proposed method was applied to a reference standard material (TM-25.2) and river water sample. Another sensitive and simple method for the speciation of $\mathrm{V}(\mathrm{IV})$ and $\mathrm{V}(\mathrm{V})$ was developed by Fan et al. [27] utilizing a separation/preconcentration step by a microcolumn packed with immobilized thenoyltrifluoroacetone (TTA) on microcrystalline naphthalene. Both of the species were trapped by microcolumn at $\mathrm{pH} 4.0$, and the vanadate $\left(\mathrm{VO}_{2}{ }^{+}\right)$ion was collected selectively at $\mathrm{pH}$ 2.4. Solid material loaded with analyte in the microcolumn was dissolved with TTA and the vanadium concentration was determined subsequently by electrothermal vaporization inductively coupled plasma optical emission spectrometry. The concentration of vanadyl $\left(\mathrm{VO}^{2+}\right)$ ion was calculated from the difference. The change in the oxidation state of vanadium species in seawater was investigated by Nukatsuka et al. [28] by selective solid phase extraction and ETAAS determination. The authors reported the strong dependence of vanadium species on the $\mathrm{pH}$ of the solutions stating that in artificial seawater at $\mathrm{pH} 7.8, \mathrm{~V}(\mathrm{~V})$ was stable but $\mathrm{V}(\mathrm{IV})$ was rapidly oxidized. In acidified ( $\mathrm{pH} 2.0$ ) artificial seawater $\mathrm{V}(\mathrm{IV}) \rightarrow \mathrm{V}(\mathrm{V})$ oxidation rate was slow. These results were reported to be in line with those obtained by Okamura et al. [29]. In a recent study by Xiong et al. [30], vanadium speciation was realized by means of a microcolumn packed with cetyltrimethylammonium bromide-modified alkyl silica. At $\mathrm{pH}$ 2.0-7.0, V(V) was quantitatively retained while $\mathrm{pH}$ 5.0-7.0 was used for the quantitative retention of $\mathrm{V}(\mathrm{IV})$. A review about the speciation of vanadium in environmental and biological samples can be found elsewhere [31].

The aim of the present study is to prepare an amine functionalized silica sorbent for the determination of vanadium species, namely $V(I V)$ and $V(V)$, in environmental samples. The sorbent was characterized using several techniques such as scanning electron microscopy-energy dispersive X-ray spectroscopy (SEM/EDS), elemental analysis, thermo gravimetric analysis (TGA), infrared spectroscopy (FTIR), and Brunauer-Emmett-Teller (BET) surface area analysis. In addition, particle size distribution and zeta potential of the proposed sorbent were also elucidated. The sorption behavior of the sorbent towards $V(I V)$ and $V(V)$ species was investigated through batch-type sorption experiments.

\section{Experimental}

\subsection{Apparatus}

The inductively coupled plasma mass spectrometer (ICP-MS) used for vanadium determination $(\mathrm{m} / \mathrm{z}=51$, natural abundance of 99.75\%) was an Agilent 7500ce (Tokyo, Japan) type instrument equipped with a high solid nebulizer, a Peltier-cooled spray chamber $\left(2^{\circ} \mathrm{C}\right)$, and an octopole collision/reaction cell with hydrogen gas pressurization (purity of 99.999\%). The ICP-MS operating conditions were as follows: forward power of $1500 \mathrm{~W}$, plasma gas flow of $15.0 \mathrm{~L} \mathrm{~min}^{-1}$, carrier gas flow of $1.1 \mathrm{~L} \mathrm{~min}^{-1}$, collision gas flow of $3.5 \mathrm{~mL} \mathrm{~min}^{-1}$; sample uptake time of $25 \mathrm{~s}$ and integration time of $100 \mathrm{~ms}$.

In batch sorption studies, GFL 1083 water bath shaker (Burgwedel, Germany) equipped with microprocessor-controlled thermostat was used to provide efficient mixing. The $\mathrm{pH}$ measurements were performed by using a Denver $\mathrm{pH} /$ ion meter (Colorado, USA) with a $\mathrm{pH} / \mathrm{ATC}$ plastic-body electrode. All reagents and chemicals were of analytical grade. Ultra pure water (18.2 M $\Omega$, Millipore, Billerica, MA, USA) was used throughout the study. Glassware and plastic ware were cleaned by soaking in $10 \%(\mathrm{v} / \mathrm{v})$ nitric acid and rinsed with distilled water prior to use. Standard V(IV) and V(V) stock solutions were prepared by dissolving appropriate amount of vanadyl sulfate pentahydrate, $\mathrm{VOSO}_{4} \cdot 5 \mathrm{H}_{2} \mathrm{O}$ (Merck, product code: 8570491 , CAS no.: [27774-13-6]) in $0.5 \mathrm{~mol} \mathrm{~L}^{-1} \mathrm{H}_{2} \mathrm{SO}_{4}$ and vanadium pentoxide, $\mathrm{V}_{2} \mathrm{O}_{5}$ (Merck, product code: 100824 CAS no.: [1314-62-1]) in $1 \%(\mathrm{v} / \mathrm{v}) \mathrm{HNO}_{3}$, respectively. Lower concentration standards were prepared daily from their stock standard solutions. Functional silane was 3-aminopropyl triethoxysilane, 
3-APTES (Merck, product code: 821619, CAS no.: [919-30-2]), and porous silica was of particle diameter 0.2-0.5 mm (Merck, product code: 107733, CAS no.: [7631-86-9]).

\subsection{Synthesis of 3-APTES-functionalized silica}

The functional silane, 3-APTES, was used as the organic source for the functionalization of the silica surface. The synthesis procedure was gathered from similar studies with some modifications [32-36]. Prior to functionalization, pretreatment of silica gel was carried out to remove the possible surface contaminants (e.g. metal ions) and activate the silanol groups on the surface. Activation was achieved by the treatment of $20.0 \mathrm{~g}$ silica gel with $100 \mathrm{~mL}$ of $0.01 \mathrm{~mol} \mathrm{~L}^{-1}$ acetic acid for $1 \mathrm{~h}$. Then it was filtered using a vacuum pump and washed with distilled water until the $\mathrm{pH}$ of the supernatant had risen to 6.0. Afterwards, it was transferred to a round bottomed flask containing $50.0 \mathrm{~mL}$ toluene and $12.0 \mathrm{~mL}$ 3-APTES. The mixture was stirred for $24 \mathrm{~h}$ under reflux at $110.0^{\circ} \mathrm{C}$ under $\mathrm{N}_{2}$ atmosphere. The resulting product was filtered off and washed with ethanol. After removal of the traces of solvent, the resulting product was dried at $50.0^{\circ} \mathrm{C}$ for $24 \mathrm{~h}$.

\subsection{Characterization}

A number of characterization methods were employed to assess the attachment of the functional groups to the silica surface. Characterization of the proposed sorbent was performed using techniques such as Brunauer-Emmett-Teller (BET) surface area analysis, Fourier transform infrared analysis (FTIR) and elemental analysis. Images of the sorbent were taken with scanning electron microscopy (SEM) while its thermal degradation behavior was investigated through TGA measurements. Particle size distribution and zeta potential of the proposed sorbent were also evaluated.

\subsection{Sorption studies}

For vanadium speciation, separate standard solutions of $\mathrm{V}(\mathrm{IV})$ and $\mathrm{V}(\mathrm{V})$, each at $1.0 \mathrm{mg} \mathrm{L}^{-1}$ concentration, were prepared at different $\mathrm{pHs}$ adjusted with various concentrations of $\mathrm{HNO}_{3}$ and $\mathrm{NH}_{3}$. From each of these solutions $10.0 \mathrm{~mL}$ was taken into which $50.0 \mathrm{mg}$ of the sorbent was added. The resulting mixture was shaken manually for 1-2 min and then for a further $30 \mathrm{~min}$ on a shaker at $25.0^{\circ} \mathrm{C}$. At the end of the shaking period, the mixture was filtered through blue-band filter paper and the filtrate was analyzed for its vanadium content by ICP-MS. The effects of $\mathrm{pH}$, sorbent amount, shaking time, initial ion concentration, solution volume and reaction temperature were investigated. The percentage of vanadium sorption was calculated using Eq. (1), where $C_{i}$ is the initial and $C_{f}$ is the final concentration in the solution.

Sorption $\%=\frac{C_{i}-C_{f}}{C_{i}} \times 100$

\subsection{Sorption isotherm models}

The equilibrium conditions of the sorption process can be described using the sorption isotherms. The relevant studies revealed the concentration-dependence of the partitioning of vanadium species between the liquid and the solid phase (sorbent) at a particular temperature. Many theoretical and empirical models have been developed to represent the various types of adsorption isotherms. The Langmuir, Freundlich and Dubinin-Radushkevich (D-R) are among the most frequently used isotherm models for this purpose.
The nonlinear form of Langmuir isotherm is given in Eq. (2)

$Q_{e}=Q_{\max } \frac{b C_{e}}{1+b C_{e}}$

where $Q_{\max }\left(\mathrm{mmol} \mathrm{g}^{-1}\right)$ and $b\left(\mathrm{~L} \mathrm{mmol}^{-1}\right)$ are Langmuir constants, $Q_{\max }$ is the amount of vanadate ion sorption corresponding to monolayer coverage, $b$ is the affinity of the species for the sorbent, $C_{e}\left(\mathrm{mmol} \mathrm{L}^{-1}\right)$ is the amount of vanadate in liquid phase at equilibrium and $Q_{e}$ is the amount of vanadate sorbed on the surface of the sorbent $\left(\mathrm{mmol} \mathrm{g}^{-1}\right)$ at equilibrium. The values of constants are evaluated from the linearized form of the equation which is given in Eq. (3):

$\frac{1}{Q_{e}}=\frac{1}{Q_{\max }}+\frac{1}{Q_{\max } b C_{e}}$

The intercept and the slope of the plot of $1 / Q_{e}$ vs. $1 / C_{e}$ were used in the determination of $Q_{\max }$ and $b$ [37-39]. Furthermore, the ability of 3-APTES-functionalized silica to accommodate vanadium ion was evaluated in terms of the maximum specific area of the sorbent. $Q_{\max }$ was used to estimate the specific surface area of the sorbents towards vanadium by Eq. (4) where $S_{a}$ is the specific surface area $\left(\mathrm{m}^{2} \mathrm{~g}^{-1}\right), Q_{\max }$ is the monolayer sorption capacity $\left(\mathrm{mg} \mathrm{g}^{-1}\right), N$ is the Avogadro Number, $A$ is the cross-sectional area of the metal ion $\left(\mathrm{m}^{2}\right)$, and $A W$ is the atomic weight of the metal [40].

$S_{a}=\frac{q_{\max } N A}{A W}$

Freundlich model is usually used to describe sorption over a wide range of concentrations on homogeneous and/or heterogeneous surfaces [41]. The isotherm is not restricted to monolayer sorption and displays various nonlinear behaviors reflected in the value of its exponential parameter $(1 / n)$. The isotherm assumes exponential increase in the sorption barrier as initial sorbate concentration is increased. The general nonlinear form of this isotherm is described by Eq. (5):

$Q_{e}=K_{F} C_{e}^{1 / n}$

where $K_{F}\left(\mathrm{mg} \mathrm{g}^{-1}\right)$ and $n$ are Freundlich constants that apply for a set of concentrations at a given temperature for a certain sorbentsorbate system. These constants are determined from the linearized form of Eq. (6) given as follows:

$\log Q_{e}=\log K_{F}+\frac{1}{n} \log C_{e}$

The intercept and the slope of $\log Q_{e}$ versus $\log C_{e}$ plot give $K_{F}$ and $1 / n$, respectively.

$D-R$ isotherm model assumes that the ionic species preferentially bind to most energetically favorable sites of sorbent associated with multilayer adsorption of ions [42]. D-R isotherm is generally described by Eqs. (7) and (8) [43]:

$Q_{e}=q_{s} \exp \left(-B \varepsilon^{2}\right)$

where

$\varepsilon=R T \ln \left(1+\frac{1}{C_{e}}\right)$

D-R parameter, $B\left(\mathrm{~mol}^{2} \mathrm{~kJ}^{-2}\right)$, gives information about the mean free energy of sorption per molecule of sorbate which is required to transfer it to the surface of the solid from infinity in the solution; $q_{s}$ $\left(\mathrm{mg} \mathrm{g}^{-1}\right)$ corresponds to the sorption monolayer capacity [44]. The mean free energy of sorption can be calculated from $D-R$ parameter $B$ by Eq. (9):

$E=(2 B)^{-(1 / 2)}$

The constants $q_{s}$ and $B$ are calculated from the intercepts and the slope of the experimental plot, $\ln Q_{e}$ versus $\varepsilon^{2}$. 
The sorption isotherm studies were also performed through batch process. In each trial, $50.0 \mathrm{mg}$ amount of 3-APTESfunctionalized silica was added into $10.0 \mathrm{~mL}$ of solution aliquots containing the specified concentrations of $\mathrm{V}(\mathrm{V})$ (ranging from 100.0 to $1000.0 \mathrm{mg} \mathrm{L}^{-1}$ ), and the mixtures were shaken in a thermostated water bath at $25.0^{\circ} \mathrm{C}$ for one hour at a pH of 2.0 . At the end of the shaking period, the solid and solution phases were separated through filtration and the concentrations of vanadium in the supernatant solutions were determined by ICP-MS. With the use of the data obtained in these experiments, the sorption capacity (maximum amount of vanadium sorbed per $g$ of silica) was also determined.

\subsection{Thermodynamic parameters}

The effect of reaction temperature on the sorption of $V(V)$ was studied at 25.0 and $60.0^{\circ} \mathrm{C}$ while keeping the other parameters constant $\left(10.0 \mathrm{~mL}\right.$ of $1.0 \mathrm{mg} \mathrm{L}^{-1} \mathrm{~V}(\mathrm{~V})$ solution, $50.0 \mathrm{mg}$ sorbent, $\mathrm{pH}$ of $2.0, n=3)$. The corresponding standard Gibbs free energy change, $\Delta G^{\mathrm{o}}$, standard enthalpy change, $\Delta H^{\mathrm{o}}$, and standard entropy change, $\Delta S^{\circ}$ were calculated utilizing the well-known Eqs. (10), (11) and (12) [45,46].

$\Delta G^{o}=-R T \ln R_{d}$

$\Delta H^{o}=R \ln \frac{R_{d}\left(T_{2}\right)}{R_{d}\left(T_{1}\right)}\left(\frac{1}{T_{1}}-\frac{1}{T_{2}}\right)^{-1}$

$\Delta S^{o}=\frac{\Delta H^{o}-\Delta G^{o}}{T}$ (13).

$R_{d}\left(\mathrm{~mL}^{-1}\right)$ is the distribution ratio of $\mathrm{V}(\mathrm{V})$ ion defined by Eq.

$R_{d}=\frac{C_{\text {solid }}}{C_{\text {liquid }}}$

where $C_{\text {solid }}$ is the concentration of $\mathrm{V}(\mathrm{V})$ on the sorbent $\left(\mathrm{mg} \mathrm{g}^{-1}\right)$ and $C_{\text {liquid }}$ is the concentration of $\mathrm{V}(\mathrm{V})$ ion in solution at the end of sorption time $\left(\mathrm{mg} \mathrm{L}^{-1}\right)$.

\subsection{Desorption studies}

Several eluents were tried for the desorption of sorbed $V(V)$ from the sorbent. For this purpose, $10.0 \mathrm{~mL}$ of $1.0 \mathrm{mg} \mathrm{L}^{-1} \mathrm{~V}(\mathrm{~V})$ was prepared and the sorption process was performed with 3-APTESfunctionalized silica as mentioned above. Following this step, the sorbent was taken into the eluent and the new mixture was shaken once again for $30 \mathrm{~min}$. Afterwards the solution was filtered and analyzed by ICP-MS. A blank solution was also prepared by the same procedure; by adding the same amount of sorbent into ultra pure water and eluting it after filtration.

\subsection{Interference studies}

The interference studies were performed with $\mathrm{Mo}(\mathrm{VI}), \mathrm{Sb}(\mathrm{III})$, $\mathrm{Sb}(\mathrm{V}), \mathrm{Te}(\mathrm{IV}), \mathrm{Te}(\mathrm{VI}), \mathrm{Se}(\mathrm{IV})$, and $\mathrm{Se}(\mathrm{VI})$ ions, in addition to various metal ions. For this purpose, 10.0, 100.0 and $1000.0 \mu \mathrm{g} \mathrm{L}^{-1}$ concentrations of the above-mentioned ions were mixed with 3-APTES-functionalized silica and the sorption behavior of the sorbent towards the listed ions was investigated. The same experimental conditions optimized for vanadate were applied in the sorption (solution volume, shaking time, solution $\mathrm{pH}$, sorbent amount and reaction temperature were $10.0 \mathrm{~mL}, 30 \mathrm{~min}, \mathrm{pH}$ of $2.0,50.0 \mathrm{mg}$, and $25.0^{\circ} \mathrm{C}$, respectively). The percent sorption of each ion was determined by ICP-MS after acidification with concentrated $\mathrm{HNO}_{3}$ to have $1.0 \%(\mathrm{v} / \mathrm{v})$ acid concentration in the final solutions.
In the second part of the interference study, $10.0 \mu \mathrm{gL}^{-1}$, $100.0 \mu \mathrm{gL}^{-1}, \quad 1000.0 \mu \mathrm{gL}^{-1}$ of the species mentioned above were added separately into $10.0 \mu \mathrm{gL}^{-1}, \quad 100.0 \mu \mathrm{gL}^{-1}$ and $1000.0 \mu \mathrm{g} \mathrm{L}^{-1} \mathrm{~V}(\mathrm{~V})$ solutions. The sorption experiments were performed under optimized conditions for vanadate as described in the previous paragraph, followed by a filtration step. After proper acidification and reduction steps ICP-MS was used for the analysis.

\subsection{Method validation and spike recovery experiments}

The efficiency of the proposed method was first checked via spike recovery tests. This was realized by spiking $10.0 \mathrm{~mL}$ aliquots of ultrapure, bottled drinking, tap, and sea water samples with $10.0 \mu \mathrm{g} \mathrm{L}^{-1}, 100.0 \mu \mathrm{g} \mathrm{L}^{-1}$ and $1000.0 \mu \mathrm{g} \mathrm{L}^{-1}$ of $\mathrm{V}(\mathrm{V})$ solutions separately and applying the batch process. After sorption, elution was performed using $0.5 \mathrm{~mol} \mathrm{~L}^{-1}$ thiourea (in $0.2 \mathrm{~mol} \mathrm{~L}^{-1} \mathrm{HCl}$ ) and shaking for 2 hours at $50.0^{\circ} \mathrm{C}$. The concentration of vanadium in the eluates was determined by ICP-MS and the percent recovery in each sample was calculated.

In addition to spike recovery experiments, a standard reference material, Trace Elements in Water (NIST, SRM 1643e) was also employed for method validation. Ten milliliters aliquots were taken and processed by the proposed methodology; sorption on the 3-APTES modified silica and elution with $0.5 \mathrm{~mol} \mathrm{~L}^{-1}$ thiourea (in $0.2 \mathrm{~mol} \mathrm{~L}^{-1} \mathrm{HCl}$ ). The eluates obtained were also analyzed by ICP-MS.

\section{Results and discussion}

\subsection{Characterization of the sorbent}

The surface morphology of unmodified and 3-APTESfunctionalized silica was examined at different surface locations using SEM. Visual inspection of the images (not shown) indicate an increase in surface roughness upon functionalization of silica. This could be reflecting a strong interaction between the silica surface and the functional groups. Based on ${ }^{29} \mathrm{Si}$ and ${ }^{13} \mathrm{C}$ NMR data of 3-APTES modified silica, it was reported that a covalent bond forms between silylating agent (3-APTES) and silanol groups which are dispersed onto the silica surface [47]. The functional groups of 3-APTES modified silica were also identified using FTIR (figure not shown). A very broad absorption band centered at $3450 \mathrm{~cm}^{-1}$ was observed which was assigned to silanols groups $(\mathrm{Si}-\mathrm{OH})$ on the surface. The vibration bands at $1200-1100$ and $470 \mathrm{~cm}^{-1}$ represented the asymmetric stretching and bending of siloxane groups ( $\mathrm{Si}-\mathrm{O}-\mathrm{Si}$ ). A band in the region of $2850-2950 \mathrm{~cm}^{-1}$ was ascribed to symmetric vibration of the $\mathrm{C}-\mathrm{H}$ groups. Absorption bands at 3450 and $1650 \mathrm{~cm}^{-1}$ represented the stretching and bending vibration of aliphatic amine $(\mathrm{N}-\mathrm{H})$ groups. Vibrations at 2947 and $1384 \mathrm{~cm}^{-1}$ were assigned to the $\mathrm{Si}-\mathrm{CH}_{2}$ stretching and bending mode, respectively. Elemental analysis was performed to reveal the percentages of $\mathrm{C}, \mathrm{H}$ and $\mathrm{N}$ in the synthesized sorbent. The observed increase in the percentages of $\mathrm{C}(6.16 \%), \mathrm{H}(1.85 \%)$ and $\mathrm{N}(2.17 \%)$ was indicative of the modification process of silica surface with 3-APTES. Calculations based upon elemental analysis yield a ligand loading of $1.55 \mathrm{mmol} \mathrm{g}^{-1}$, with the overall fractional loading efficiency being 0.60 .

The thermogravimetric analysis allowed the determination of the degree of surface modification through comparison of the percent weight loss as a function of temperature. With the use of the thermographs obtained for unmodified and 3-APTESfunctionalized silica, a $3-4 \%$ weight loss observed at $\sim 110^{\circ} \mathrm{C}$ was attributed to the removal of adsorbed water from the silica structure. Beyond $200^{\circ} \mathrm{C}$, the weight decreased gradually and about $7 \%$ 


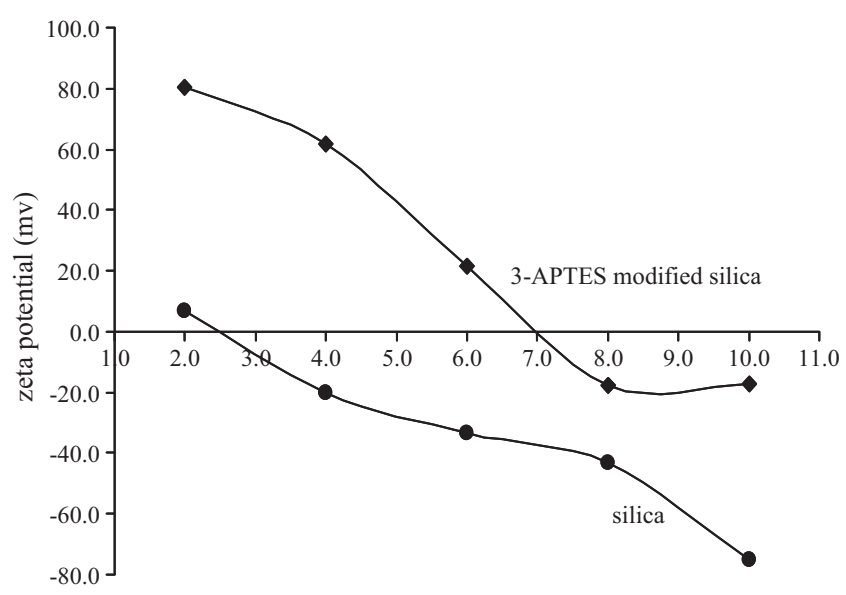

$\mathrm{pH}$

Fig. 1. Effect of pH on zeta potential of unmodified and 3-APTES-functionalized silica (100.0 mg sorbent, $50.0 \mathrm{~mL}$ sample volume).

weight loss was observed up to $620^{\circ} \mathrm{C}$. The total loss from the sample was about $10-13 \%$ around $620^{\circ} \mathrm{C}$ indicating that silica gel is modified with an organic compound. The difference in the weight loss compared to that of the unmodified silica can be attributed to the modification of the surface.

Determination of the specific surface areas of unmodified and functionalized silica is essential to express concentration of reactive surface species. Nitrogen sorption isotherm data can be used for this purpose, that is, for providing information about the pore system of materials. The pore volume and pore size can be expected to decrease upon modification with the functionalized silane due to space occupancy. Accordingly, the decrease in the pore volume from 0.101 to $0.065 \mathrm{~cm}^{3} \mathrm{~g}^{-1}$ is likely to be an indication of the organic groups having been successfully introduced into the inner channels. In line with this, the decrease in specific surface area by nitrogen adsorption indicates the coverage of the silica surface with the functional groups. These findings are in accordance with the previous studies [48]. It was reported that nitrogen molecules were adsorbed preferentially to silanols and a weak adsorption was observed on organic surfaces compared with bare silica surfaces.

The zeta potential measurements (Fig. 1) were carried out as a function of $\mathrm{pH}$ and the zero point of charge (zpc) of the unmodified silica and 3-APTES-functionalized silica was, respectively, determined to be 2.5 and 7.0. The zpc values indicate that the electrostatic nature of the two sorbents is significantly different. The particle size measurements indicated that as the surface modification is performed, smaller silica particles are obtained. This is probably due to mechanical abrasion caused by stirring during the synthesis process. In addition, the particle size distribution of the novel sorbent has also indicated a monodispersed distribution of particles.

\subsection{Sorption studies}

Calibration standards were prepared from $1000.0 \mathrm{mg} \mathrm{L}^{-1} \mathrm{~V}(\mathrm{IV})$ and $\mathrm{V}(\mathrm{V})$, respectively, with simple dilution. All standards contained $1.0 \%(\mathrm{v} / \mathrm{v}) \mathrm{HNO}_{3}$ corresponding to a $\mathrm{HNO}_{3}$ concentration of $0.144 \mathrm{~mol} \mathrm{~L}^{-1}$ and were measured with ICP-MS. Similar responses were obtained with both species and the graphs were linear at least up to $1000.0 \mu \mathrm{g} \mathrm{L}^{-1}$. The limit of detection (LOD) based on $3 \mathrm{~s}$ ( 3 times the standard deviation above the blank value) was $0.041 \mu \mathrm{g} \mathrm{L}^{-1}$. When the detection limits of several detection methods for the determination of vanadium are compared, it can be said that the detection limit of the proposed method is comparable or lower than most of those reported in the literature (Table 1).

\subsubsection{Effect of $p H$}

The solution $\mathrm{pH}$ is one of the most crucial factors in controlling the sorption of vanadium species by a given sorbent. As mentioned before, vanadium can be found in +4 oxidation state as vanadyl cation, $\mathrm{VO}^{2+}$, in reducing media and is stable in acidic solution below $\mathrm{pH} 2$. Alternatively, it may exist in +5 oxidation state as vanadate cation, $\mathrm{VO}_{2}{ }^{+}$, in acidic solutions. In the presence of oxidizing agents, vanadium ion can prevail as the hydrated monomer of vanadate $\left(\mathrm{HVO}_{4}{ }^{2-}\right.$ or $\left.\mathrm{H}_{2} \mathrm{VO}_{4}{ }^{-}\right)$at micromolar concentrations near neutral $\mathrm{pH}$, as $\mathrm{H}_{2} \mathrm{VO}_{4}{ }^{-}$in neutral solutions, and as $\mathrm{HV}_{2} \mathrm{O}_{7}{ }^{3-}$ in alkaline solutions. Depending on the $\mathrm{pH}$ and species concentrations, several monomeric and polymeric tetravalent and pentavalent vanadium species can also be present in aqueous solutions. Based on this, among the investigated parameters, priority was given to elucidating the effect of $\mathrm{pH}$ on vanadium uptake by the sorbents. The obtained results for $\mathrm{V}(\mathrm{IV})$ and $\mathrm{V}(\mathrm{V})$ sorption by 3-APTES-functionalized and unmodified silica as a function of $\mathrm{pH}$ are shown in Fig. 2(a,b).

As can be seen from Fig. 2a, the speciation capability of 3-APTESfunctionalized silica is mostly pronounced at $\mathrm{pH} 2.0$; with greater than $90 \%$ sorption corresponding to $\mathrm{V}(\mathrm{V})$ species compared to less than $10 \%$ for $V(I V)$. On the other hand, there is a strong similarity between the sorption properties of unmodified and functionalized silica towards both vanadium species at $\mathrm{pHs}$ higher than 3.0 with a slight difference in the sorption percentages at $\mathrm{pH}$ 9.0. At first

Table 1

Comparison of detection limits of some methods for vanadium determination.

\begin{tabular}{|c|c|c|c|c|c|}
\hline $\begin{array}{l}\text { Complexing reagent or solid } \\
\text { phase }\end{array}$ & Elution solvent & Detection method & Detection limit & Matrix & Ref. \\
\hline Quinine modified resin & Hydrochloric acid & FETV-ICP-OES & $0.072 \mu \mathrm{g} \mathrm{L}^{-1}$ & Water samples & {$[20]$} \\
\hline $\begin{array}{l}\text { Anion exchange column, } \\
\text { V-EDTA complexes }\end{array}$ & Carbonate buffer & HPLC-ICP-MS & $0.025 \mu \mathrm{g} \mathrm{L}^{-1}$ & Natural mineral water & [21] \\
\hline $\begin{array}{l}\text { Palmitoyl quinolin-8-ol } \\
\text { bonded amberlite XAD } 2\end{array}$ & Hydrochloric acid & UV & $1.6 \mu \mathrm{g} \mathrm{L}^{-1}$ & Seawater & {$[22]$} \\
\hline $\begin{array}{l}\text { Bakers' yeast immobilised on } \\
\text { controlled pore glass }\end{array}$ & Hydrochloric acid & ICP-OES & $0.06 \mu \mathrm{g} \mathrm{L}^{-1}$ & Tap and river water & {$[24]$} \\
\hline $\begin{array}{l}\text { L-methionine immobilised on } \\
\text { controlled pore glass }\end{array}$ & Hydrochloric acid & ICP-OES & $0.008 \mu \mathrm{g} \mathrm{L}^{-1}$ & Urine & [25] \\
\hline $\begin{array}{l}\text { Aminopropyl-silica gel, } \\
\text { modified with Tetrakis } \\
\text { (4-carboxyphenyl) } \\
\text { porphyrin }\end{array}$ & Nitric acid & AAS & $1.15 \mu \mathrm{g} \mathrm{L}^{-1}$ & River water & [26] \\
\hline $\begin{array}{c}\text { Thenoyltrifluoroacetone (TTA) } \\
\text { on microcrystalline column }\end{array}$ & Acetone & ETV-ICP-OES & $0.068 \mu \mathrm{g} \mathrm{L}^{-1}$ & Natural water & [28] \\
\hline 3-APTES modified silica & Thiourea in $\mathrm{HCl}$ & ICP-MS & $0.041 \mu \mathrm{g} \mathrm{L}^{-1}$ & $\begin{array}{l}\text { Tap, drinking and sea } \\
\text { water }\end{array}$ & This work \\
\hline
\end{tabular}



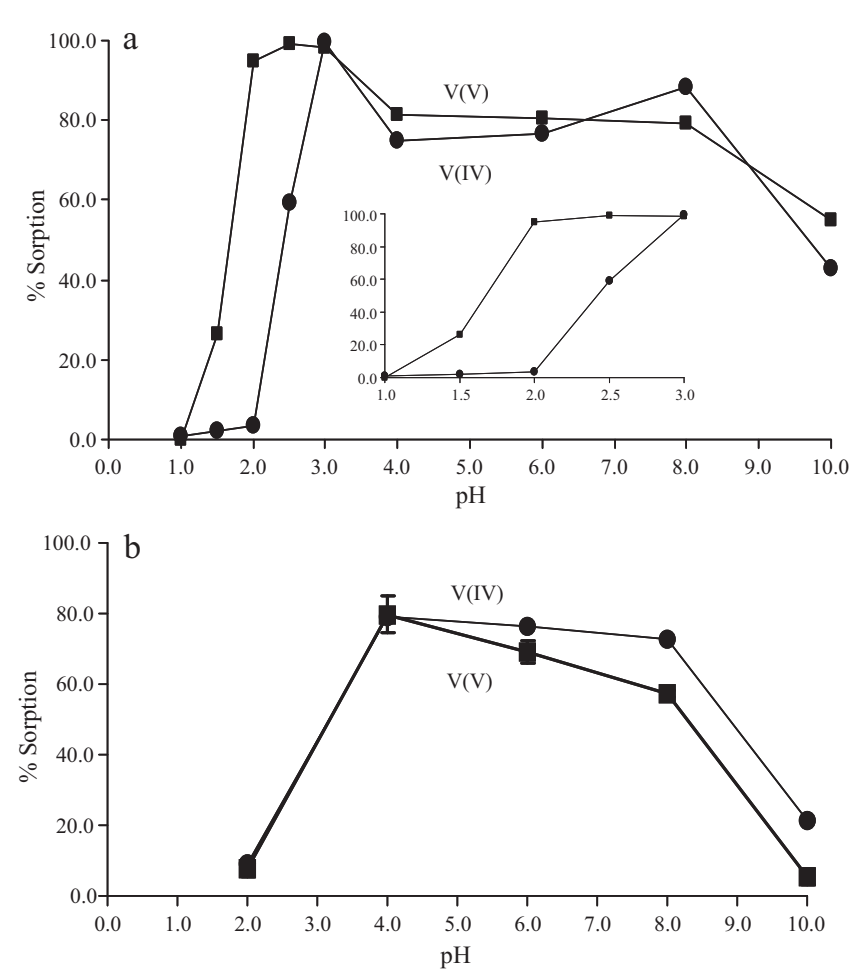

Fig. 2. Effect of pH on the sorption of (a) 3-APTES-functionalized and (b) unmodi-

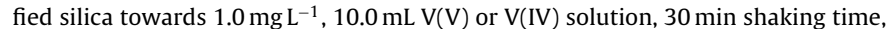
$50.0 \mathrm{mg}$ sorbent at $25.0^{\circ} \mathrm{C}$ sorption temperature $(n=3)$. Inset in $(\mathrm{a})$ is the exaggerated view of "\% sorption versus $\mathrm{pH}$ " graph for $\mathrm{pHs}$ between 1.0 and 3.0. (Note: In most of the measurements, the results were quite reproducible that the error bars cannot be differentiated. The same situation applies also to the results given in the other figures.)

glance, for $\mathrm{pH}$ values higher than 3.0, it can be observed that both of $\mathrm{V}(\mathrm{IV})$ and $\mathrm{V}(\mathrm{V})$ are taken up by the sorbent to a certain degree (40-80\% depending on $\mathrm{pH}$ ) and that the sorbent does not show any selectivity to $\mathrm{V}(\mathrm{IV})$ or $\mathrm{V}(\mathrm{V})$. However, a healthier comment would be that a possible oxidation of $\mathrm{V}(\mathrm{IV})$ to $\mathrm{V}(\mathrm{V})$ at $\mathrm{pH}$ 's higher than 3.0 is taking place, and is thus leading the sorbent to exhibit sorption only towards $\mathrm{V}(\mathrm{V})$. This finding is also in accordance with the results of the previous studies which report the oxidation of $\mathrm{V}(\mathrm{IV})$ to $\mathrm{V}(\mathrm{V})$ near neutral pHs $[29,30]$. It was also reported by Nukatsuka et al. [29] that especially in seawater containing organic matter, there is the possibility of reduction of $\mathrm{V}(\mathrm{V})$ to $\mathrm{V}(\mathrm{IV})$ at $\mathrm{pH} 2.0$ which dictates the immediate processing of samples if acidic pHs are to be used for speciation. In a study by Ekinci and Köklü [37], a similar sorbent functionality was used for several metal ions including vanadium but no speciation results were given; and the sorbent used displayed maximum retention towards vanadium at $\mathrm{pHs}$ greater than 8.0.

The results from the references and the present study indicate the importance of $\mathrm{pH}$ adjustment prior to the sorption step. Since, even unmodified silica retains $\mathrm{V}(\mathrm{V})$ in basic pHs (Fig. $2 \mathrm{~b}$ ) and can be used for the sorption of low concentrations of $\mathrm{V}(\mathrm{V})$, the importance of functionalization of silica with 3-APTES is emphasized in acidic pHs between 1.0 and 3.0, as demonstrated in Fig. 2a. Consequently, a solution $\mathrm{pH}$ of 3.0 can be used for the quantitative sorption of both $\mathrm{V}(\mathrm{IV})$ and $\mathrm{V}(\mathrm{V})$, whereas $\mathrm{pH}$ of 2.0 , with immediate processing of the samples to avoid any possible reduction, would allow only for the sorption of $\mathrm{V}(\mathrm{V})$. The concentration of $\mathrm{V}(\mathrm{IV})$ can be determined from the difference.

\subsubsection{Effect of sorbent amount and shaking time}

The optimum amount of the sorbent for maximum uptake was determined by varying the weight of 3-APTES-functionalized
Table 2

Effect of initial $\mathrm{V}(\mathrm{V})$ concentration on the sorption by unmodified and 3-APTESfunctionalized silica $(50.0 \mathrm{mg}$ sorbent, $30.0 \mathrm{~min}$ sorption time, solution $\mathrm{pH}$ of 2.0 , $10.0 \mathrm{~mL}$ solution volume, $n=3$ ).

\begin{tabular}{cll}
\hline Concentration $\left(\mathrm{mg} \mathrm{L}^{-1}\right)$ & $\begin{array}{l}\text { Unmodified } \\
\text { silica }\end{array}$ & $\begin{array}{l}\text { 3-APTES-functionalized } \\
\text { silica }\end{array}$ \\
\hline 0.010 & $39.5( \pm 5.9)$ & $91.2( \pm 0.2)$ \\
0.10 & $6.3( \pm 1.2)$ & $97.3( \pm 0.3)$ \\
1.0 & $7.7( \pm 2.2)$ & $97.8( \pm 0.7)$ \\
10.0 & $2.9( \pm 2.0)$ & $95.9( \pm 0.6)$ \\
100.0 & $7.7( \pm 3.3)$ & $93.5( \pm 0.9)$ \\
1000.0 & $7.9( \pm 0.4)$ & $60.6( \pm 4.3)$ \\
\hline
\end{tabular}

silica (5.0-200.0 mg) while keeping the other parameters constant ( $10.0 \mathrm{~mL}$ of $1.0 \mathrm{mg} \mathrm{L}^{-1} \mathrm{~V}(\mathrm{~V})$ solution, $\mathrm{pH}$ of 2.0 , reaction temperature of $25.0^{\circ} \mathrm{C}$ ). The maximum sorption was observed at $50.0 \mathrm{mg}$ and, thus, this amount was assumed to be adequate for quantitative sorption of $\mathrm{V}(\mathrm{V})$ under the employed experimental conditions.

Similarly, the equilibration time between $\mathrm{V}(\mathrm{V})$ and the sorbent was determined by changing the shaking time between 1-90 min while keeping the other parameters constant $(50.0 \mathrm{mg}$ sorbent, $10.0 \mathrm{~mL}$ of $1.0 \mathrm{mg} \mathrm{L}^{-1} \mathrm{~V}(\mathrm{~V})$ solution, $\mathrm{pH}$ of 2.0 , reaction temperature of $25.0^{\circ} \mathrm{C}$ ). The results demonstrated the very fast kinetics of sorption; even a reaction time of 5 min was sufficient to achieve equilibrium (95\% sorption). Still, a shaking time of $30 \mathrm{~min}$ was used to guarantee the quantitative sorption keeping in mind that this is a rather short period of time for $V(V) \rightarrow V(I V)$ reduction for which a half life of about $3 \mathrm{~h}$ was reported [29]. Although the relatively fast kinetics of the sorption recalled the use of the functionalized sorbent in micro/mini columns for SPE, the small diameter of the particles precluded this possibility due to the back-pressure created during the operation.

\subsubsection{Effect of initial ion concentration}

The extent of removal of heavy metals from aqueous solutions depends strongly on the initial concentration of the metal. The sorption percentage of $\mathrm{V}(\mathrm{V})$ by 3-APTES-functionalized silica at various initial concentrations was studied under the optimum conditions (50.0 mg sorbent, $10.0 \mathrm{mLV}(\mathrm{V})$ solution, $\mathrm{pH}$ of 2.0 , reaction temperature of $25.0^{\circ} \mathrm{C}$ ). The obtained results are given in Table 2 . In order to demonstrate the efficiency of the surface modification of silica with the amino functional group, parallel experiments were also conducted with the unmodified silica. As can be seen from the table, $\mathrm{V}(\mathrm{V})$ is not quantitatively retained by the unmodified silica at $\mathrm{pH}$ 2.0. When 3-APTES-functionalized silica is considered, it is seen that the sorption percentage does not decrease below 93.5 $( \pm 0.9) \%$ until an initial concentration of $100.0 \mathrm{mg} \mathrm{L}^{-1}$. The decrease in percentage sorption at the initial concentration of $1000.0 \mathrm{mg} \mathrm{L}^{-1}$ is due to exceeding the maximum sorption capacity of the sorbent (detailed information will be given in the subsequent sections). The decrease in the percentage sorption with an increase in the initial metal ion concentration stems from the steeper increase in the number of ions remaining in solution in comparison to those fixed by the solid surface.

\subsubsection{Effect of ionic strength}

The effect of ionic strength on the sorption percentage of 3-APTES-functionalized silica was studied by the addition of various concentrations of $\mathrm{NaCl}\left(0.001-0.100 \mathrm{~mol} \mathrm{~L}^{-1}\right)$ into $\mathrm{V}(\mathrm{V})$ solution while keeping the other parameters constant $\left(1.0 \mathrm{mg} \mathrm{L}^{-1}\right.$, $10.0 \mathrm{mLV}(\mathrm{V})$ solution, $30 \mathrm{~min}$ shaking time, $50.0 \mathrm{mg}$ sorbent, $\mathrm{pH}$ $2.0,25.0^{\circ} \mathrm{C}$ sorption temperature, $\mathrm{n}=3$ ). According to the results, almost no change in sorption percentage was observed even in a relatively high concentration of $\mathrm{NaCl}\left(0.100 \mathrm{~mol} \mathrm{~L}^{-1}\right)$. This finding can be assumed to demonstrate the potential application of the novel sorbent to relatively heavy sample matrixes. 
Table 3

Effect of sample volume on sorption of $V(V)$ by 3-APTES-functionalized silica $\left(10.0 \mu \mathrm{g} \mathrm{V}(\mathrm{V}), 100.0 \mathrm{mg}\right.$ sorbent, $30 \mathrm{~min}$ sorption time, $\mathrm{pH}$ of $2.0,25.0^{\circ} \mathrm{C}$ sorption temperature, $n=3$ ).

\begin{tabular}{cll}
\hline Sample volume $(\mathrm{mL})$ & $\mathrm{V}(\mathrm{V})$ concentration $\left(\mathrm{mg} \mathrm{L}^{-1}\right)$ & \% Sorption \\
\hline 10.0 & 1.0 & $99.2( \pm 0.2)$ \\
25.0 & 0.40 & $98.1( \pm 0.6)$ \\
50.0 & 0.20 & $97.5( \pm 0.6)$ \\
100.0 & 0.10 & $93.7( \pm 0.5)$ \\
250.0 & 0.04 & $87.1( \pm 1.0)$ \\
500.0 & 0.02 & $63.1( \pm 0.3)$ \\
1000.0 & 0.01 & $40.7( \pm 2.2)$ \\
\hline
\end{tabular}

Table 4

Effect of sample volume on sorption of $V(V)$ by 3-APTES-functionalized silica (1.0 $\mathrm{mg} \mathrm{L}^{-1} \mathrm{~V}(\mathrm{~V}), 100.0 \mathrm{mg}$ of sorbent, $30 \mathrm{~min}$ sorption time, $\mathrm{pH}$ of $2.0,25.0^{\circ} \mathrm{C}$ sorption temperature, $n=3$ ).

\begin{tabular}{clc}
\hline Sample volume $(\mathrm{mL})$ & $\mathrm{V}(\mathrm{V})$ concentration $\left(\mathrm{mg} \mathrm{L}^{-1}\right)$ & \% Sorption \\
\hline 10.0 & 1.0 & $99.2( \pm 0.2)$ \\
25.0 & 1.0 & $99.4( \pm 0.1)$ \\
50.0 & 1.0 & $95.7( \pm 0.8)$ \\
100.0 & 1.0 & $88.5( \pm 0.2)$ \\
250.0 & 1.0 & $66.4( \pm 0.6)$ \\
500.0 & 1.0 & $40.0( \pm 1.2)$ \\
1000.0 & 1.0 & $17.5( \pm 3.5)$ \\
\hline
\end{tabular}

Table 5

Effect of sorbent amount on sorption of $1000 \mathrm{~mL}, 1.0 \mathrm{mg} \mathrm{L}^{-1} \mathrm{~V}(\mathrm{~V})$ by 3-APTESfunctionalized silica ( $30 \mathrm{~min}$ sorption time, $\mathrm{pH}$ of $2.0,25.0^{\circ} \mathrm{C}$ sorption temperature, $n=3)$.

\begin{tabular}{llll}
\hline $\begin{array}{l}\text { Sample } \\
\text { volume }(\mathrm{mL})\end{array}$ & $\begin{array}{l}\text { Sorbent } \\
\text { amount }(\mathrm{g})\end{array}$ & $\begin{array}{l}\mathrm{V}(\mathrm{V}) \text { concentration } \\
\left(\mathrm{mg} \mathrm{L}^{-1}\right)\end{array}$ & \% Sorption \\
\hline 1000.0 & 0.1 & 1.0 & $17.5( \pm 2.6)$ \\
1000.0 & 0.2 & 1.0 & $37.6( \pm 3.5)$ \\
1000.0 & 0.5 & 1.0 & $81.3( \pm 1.5)$ \\
1000.0 & 1.0 & 1.0 & $91.3( \pm 2.5)$ \\
1000.0 & 2.0 & 1.0 & $98.8( \pm 3.5)$ \\
\hline
\end{tabular}

\subsubsection{Effect of sample volume}

The usage of preconcentration methods is a common approach for the determination of low concentrations of analytes. Depending on the final concentration and sample volume required, different preconcentration factors can be selected. In the present study, the effect of sample volume was investigated by two strategies. In the first, 10.0, 25.0, 50.0, 100.0, 250.0, 500.0 and $1000.0 \mathrm{~mL}$ sample volumes containing the same absolute amount of $\mathrm{V}(\mathrm{V})(10.0 \mu \mathrm{g})$ were processed with the proposed methodology while the other parameters were held constant at the optimum values. According to the results outlined in Table 3, it can be said that acceptable recoveries (>87\%) were obtained with sample volumes less than $250.0 \mathrm{~mL}$. On the other hand, percent sorption decreased with increasing sample volumes beyond $250.0 \mathrm{~mL}$ under the conditions applied. In the second case, $\mathrm{V}(\mathrm{V})$ concentration was kept constant at $1.0 \mathrm{mg} \mathrm{L}^{-1}$ while the sample volume was changed $(10.0,25.0,50.0,100.0,250.0$, 500.0 and $1000.0 \mathrm{~mL}$ ). The results given in Table 4 demonstrate that the proposed methodology can be applied efficiently (>88\% sorption) for sample volumes less than $100.0 \mathrm{~mL}$. Sorption percentage deteriorates after $250.0 \mathrm{~mL}$ due to the decreased sorption capacity of the sorbent. However, this deficiency can be overcome with the use of higher amounts of 3-APTES-functionalized silica as shown in Table 5.

\subsection{Sorption isotherm models}

A comparison of Langmuir, Freundlich, and DubininRadushkevich adsorption models was made for the sorption

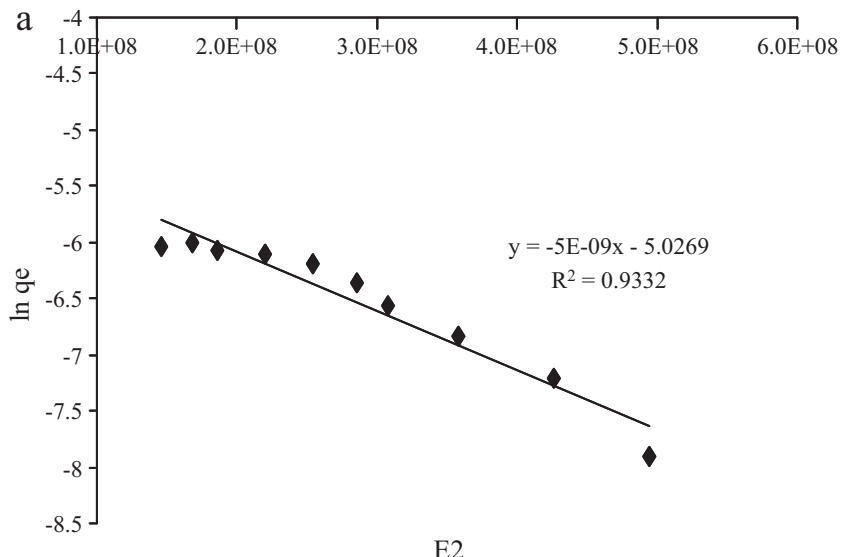

E2

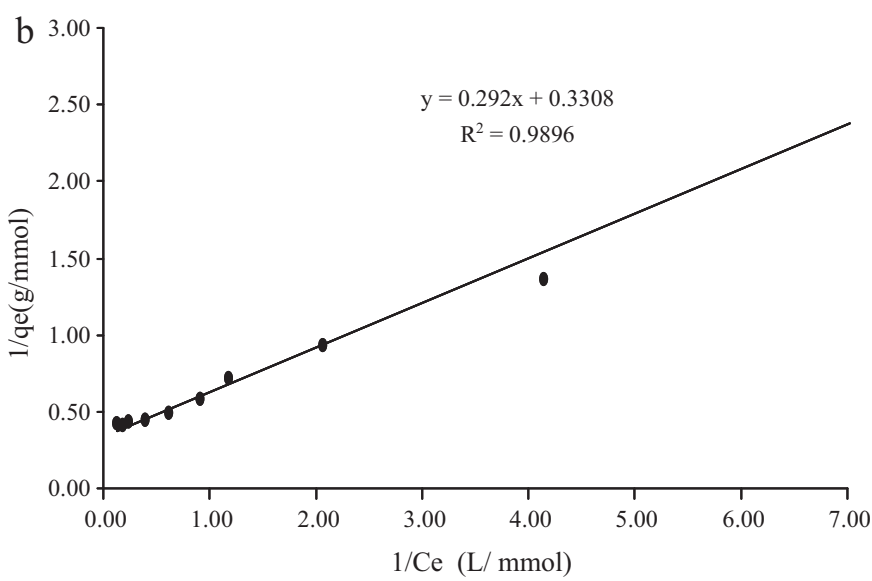

C
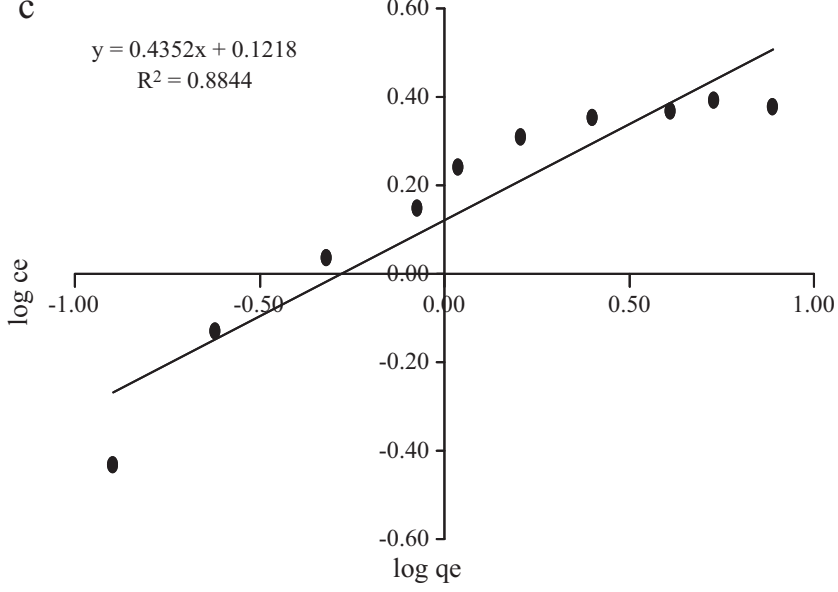

Fig. 3. Linear fits of (a) Langmuir, (b) Freundlich, (c) Dubinin-Radushkevich models for vanadate sorption by 3-APTES-functionalized silica.

of $\mathrm{V}(\mathrm{V})$ by 3-APTES-functionalized silica at $\mathrm{pH} 2.0$ and $25.0^{\circ} \mathrm{C}$. Among the three isotherm models, Langmuir isotherm showed the best correlation with the experimental data within the whole concentration range as reflected by its highest correlation coefficient. The validity of the Langmuir isotherm suggests a monolayer coverage and this assumption can be utilized to estimate the theoretical specific surface area. Based on this approach, the surface area was calculated to be $102.5 \mathrm{~m}^{2} \mathrm{~g}^{-1}$. The linear fits of the three isotherms (Langmuir, Freundlich, and Dubinin-Radushkevich) are illustrated in Fig. 3, and the corresponding isotherm parameters are summarized in Table 6. 
Table 6

Summary of models coefficients.

\begin{tabular}{lll}
\hline Adsorption model & Parameter & \\
\hline Langmuir & $R^{2}$ & 0.9896 \\
& $Q_{\max }\left(\mathrm{mmol} \mathrm{g}^{-1}\right)$ & 3.02 \\
Freundlich & $\mathrm{B}\left(\mathrm{Lmml}^{-1}\right)$ & 0.88 \\
& $R^{2}$ & 0.884 \\
& $K_{\mathrm{F}}\left(\mathrm{mg} \mathrm{g}^{-1}\right)$ & 1.32 \\
Dubinin- & $1 / n$ & 0.44 \\
Radushkevich & $R^{2}$ & 0.933 \\
& $B\left(\mathrm{~mol}^{2} \mathrm{~kJ}^{-2}\right)$ & $5 \times 10^{-9}$ \\
& $q_{\mathrm{s}}$ & 0.007 \\
\hline
\end{tabular}

Table 7

Thermodynamic parameters for the sorption of $V(V)$ by 3-APTES-functionalized silica.

\begin{tabular}{llllll}
\hline \multicolumn{2}{l}{$\Delta G^{\circ}\left(\mathrm{kJ} \mathrm{mol}^{-1}\right)$} & & $\Delta H^{\circ}\left(\mathrm{kJ} \mathrm{mol}^{-1}\right)$ & & \multicolumn{2}{c}{$\Delta S^{\circ}\left(\mathrm{J} \mathrm{mol}^{-1} \mathrm{~K}^{-1}\right)$} \\
\cline { 4 - 6 } $298 \mathrm{~K}$ & $333 \mathrm{~K}$ & & & $298 \mathrm{~K}$ & $333 \mathrm{~K}$ \\
\hline-8.7 & -11.5 & -15.6 & -281.6 & -243.5 \\
\hline
\end{tabular}

\section{Table 8}

Percent sorption of chosen species by 3-APTES-functionalized silica at the optimized conditions for $\mathrm{V}(\mathrm{V}), 50.0 \mathrm{mg}$ sorbent, $10.0 \mathrm{~mL}$ solution volume, $\mathrm{pH} 2.0,25.0^{\circ} \mathrm{C}$ solution temperature and $30.0 \mathrm{~min}$ sorption time, $n=3$.

\begin{tabular}{llll}
\hline & \multicolumn{2}{l}{ \% Sorption } & \\
\cline { 2 - 4 } & $10.0 \mu \mathrm{g} \mathrm{L}^{-1}$ & $100.0 \mu \mathrm{g} \mathrm{L}^{-1}$ & $1000.0 \mu \mathrm{g} \mathrm{L}^{-1}$ \\
\hline $\mathrm{As}(\mathrm{III})$ & $61.6( \pm 2.7)$ & $20.7( \pm 3.9)$ & $17.0( \pm 3.8)$ \\
$\mathrm{As}(\mathrm{V})$ & $11.7( \pm 2.7)$ & $\sim 0$ & $\sim 0$ \\
$\mathrm{Fe}(\mathrm{II})$ & $\sim 0$ & $\sim 0$ & $\sim 0$ \\
$\mathrm{Fe}(\mathrm{III})$ & $88.3( \pm 6.2)$ & $58.4( \pm 5.3)$ & $44.8( \pm 4.5)$ \\
$\mathrm{Mo}(\mathrm{VI})$ & $100.0( \pm 0.5)$ & $100.0( \pm 0.2)$ & $100.0( \pm 0.5)$ \\
$\mathrm{Sb}(\mathrm{III})$ & $100.0( \pm 0.5)$ & $99.5( \pm) 0.3$ & $88.8( \pm 0.2)$ \\
$\mathrm{Sb}(\mathrm{V})$ & $\sim 0$ & $\sim 0$ & $\sim 0$ \\
$\mathrm{Se}(\mathrm{IV})$ & $100.0( \pm 0.2)$ & $62.0( \pm 6.8)$ & $63.9( \pm 5.9)$ \\
$\mathrm{Se}(\mathrm{VI})$ & $90.1( \pm 0.2)$ & $92.3( \pm 0.2)$ & $95.5( \pm 0.1)$ \\
$\mathrm{Te}(\mathrm{IV})$ & $\sim 0$ & $\sim 0$ & $\sim 0$ \\
$\mathrm{Te}(\mathrm{VI})$ & $82.0( \pm 4.9)$ & $21.1( \pm 1.3)$ & $7.8( \pm 1.4)$ \\
\hline
\end{tabular}

\subsection{Effect of sorption temperature}

The effect of reaction temperature on the sorption of $\mathrm{V}(\mathrm{V})$ was studied at 25.0 and $60.0^{\circ} \mathrm{C}$. The change in the percent sorption of 3-APTES-functionalized silica as a function of temperature was investigated and a decreased sorption with an increase in the temperature was observed. The apparent exothermic behavior was associated with a decrease in entropy, indicating that the spontaneous sorption is enthalpy-driven (Table 7).

\subsection{Desorption from the sorbent}

Among the various concentrations of acids, bases, oxidants/reductants, and complexing agents $\left(\mathrm{HCl}, \mathrm{HNO}_{3}, \mathrm{H}_{3} \mathrm{PO}_{4}\right.$,
Table 10

Spike recovery results for vanadate ion with ultra-pure, bottled-drinking, tap and sea water samples after desorption from 3-APTES-functiolized silica (50.0 mg sorbent, $10 \mathrm{~mL}$ sample volume, $\mathrm{pH} 2.0,25.0^{\circ} \mathrm{C}$ solution temperature and $30.0 \mathrm{~min}$ sorption time; eluent: $0.5 \mathrm{M}$ thiourea, $n=3$ ).

\begin{tabular}{lrlr}
\hline Water type & $\mathrm{V}(\mathrm{V})$ spike $\left(\mu \mathrm{g} \mathrm{L}^{-1}\right)$ & $\mathrm{V}(\mathrm{V})$ found $\left(\mu \mathrm{g} \mathrm{L}^{-1}\right)$ & Recovery \% \\
\hline Ultra pure & 10.0 & $10.8( \pm 1.3)$ & $108.0( \pm 13)$ \\
& 100.0 & $90.0( \pm 4.5)$ & $90.0( \pm 4.5)$ \\
Bottled- & 1000.0 & $930( \pm 3)$ & $93.0( \pm 0.3)$ \\
drinking & 10.0 & $10.8( \pm 0.3)$ & $108.1( \pm 3.0)$ \\
& 100.0 & $89.4( \pm 3.1)$ & $89.4( \pm 3.1)$ \\
Tap & 1000.0 & $960( \pm 5)$ & $96.0( \pm 0.5)$ \\
& 10.0 & $9.9( \pm 1.2)$ & $99.0( \pm 12)$ \\
Sea & 100.0 & $91.8( \pm 4.0)$ & $91.8( \pm 4.0)$ \\
& 1000.0 & $870( \pm 3)$ & $87.0( \pm 0.3)$ \\
& 10.0 & $9.9( \pm 0.4)$ & $99.0( \pm 4.0)$ \\
& 100.0 & $93.3( \pm 1.1)$ & $93.3( \pm 1.1)$ \\
& 1000.0 & $730( \pm 3)$ & $73.0( \pm 0.3)$ \\
\hline
\end{tabular}

$\mathrm{H}_{2} \mathrm{SO}_{4}$, ascorbic acid, tartaric acid, EDTA, CDTA, KI, KSCN, thiourea, L-cysteine, citric acid, etc.) tried for desorption of $\mathrm{V}(\mathrm{V})$ from 3-APTES-functionalized silica, only $0.5 \mathrm{~mol} \mathrm{~L}^{-1}$ thiourea (in $0.2 \mathrm{~mol} \mathrm{~L}^{-1} \mathrm{HCl}$ ) gave efficient desorption $(93( \pm 3) \%)$ while the elution percentage for the others changed between 10 and $80 \%$. Therefore, $0.5 \mathrm{~mol} \mathrm{~L}^{-1}$ thiourea (in $0.2 \mathrm{~mol} \mathrm{~L}^{-1} \mathrm{HCl}$ ) was used as the eluent in further studies.

\subsection{Interference studies}

In order to perform a detailed interference study, initial experiments were planned to elucidate the extent of sorption of 3-APTES-functionalized silica towards several metal ions at $\mathrm{pH} 2.0$ at which $\mathrm{V}(\mathrm{IV})$ and $\mathrm{V}(\mathrm{V})$ can be separated. The sorbent showed no significant selectivity towards $\mathrm{Al}, \mathrm{B}, \mathrm{Ba}, \mathrm{Cd}, \mathrm{Co}, \mathrm{Cr}, \mathrm{Li}, \mathrm{Mg}, \mathrm{Mn}, \mathrm{Ni}$, $\mathrm{Pb}, \mathrm{Sr}, \mathrm{Tl}$ and $\mathrm{Zn}$. A similar interference study was conducted also with $\mathrm{As}(\mathrm{III}), \mathrm{As}(\mathrm{V}), \mathrm{Fe}(\mathrm{II}), \mathrm{Fe}(\mathrm{III}), \mathrm{Mo}(\mathrm{VI}), \mathrm{Sb}(\mathrm{III}), \mathrm{Sb}(\mathrm{V}), \mathrm{Se}(\mathrm{IV}), \mathrm{Se}(\mathrm{VI})$, $\mathrm{Te}(\mathrm{IV})$ and $\mathrm{Te}(\mathrm{VI})$, as described previously. The results given in Table 8 show that 3 -APTES-functionalized silica exhibits significant sorption towards the species, especially at low ion concentrations, except for $\mathrm{Fe}(\mathrm{II}), \mathrm{Sb}(\mathrm{V}), \mathrm{Te}(\mathrm{IV})$ and $\mathrm{As}(\mathrm{V})$. The oxyanions of Mo(VI), $\mathrm{Sb}(\mathrm{III})$ and $\mathrm{Se}(\mathrm{VI})$ were almost completely removed from the solutions at all concentrations tested. This finding, i.e. the selectivity of the novel sorbent to $\mathrm{Mo}(\mathrm{VI}), \mathrm{Sb}(\mathrm{III})$, and $\mathrm{Se}(\mathrm{VI})$, can offer a new potential for the selective determination of these ions in addition to $\mathrm{V}(\mathrm{IV}) / \mathrm{V}(\mathrm{V})$ speciation.

Based on the previous results, the interference effects of As(III), $\mathrm{Fe}(\mathrm{III}), \mathrm{Mo}(\mathrm{VI}), \mathrm{Sb}(\mathrm{III}), \mathrm{Se}(\mathrm{IV}), \mathrm{Se}(\mathrm{VI}), \mathrm{Te}(\mathrm{IV})$ on $\mathrm{V}(\mathrm{V})$ sorption were investigated in such a way that various concentrations of the ions were prepared and spiked with $\mathrm{V}(\mathrm{V})$. Any effect causing at least $15 \%$ decrease in the sorption was considered as interference. Table 9 shows the effect of each species on sorption as a function of $V(V)$ concentration. As given in the table, all three investigated concentrations of Te(IV), Se(IV), Se(VI), and Fe(III) showed interference by decreasing the percent sorption of $\mathrm{V}(\mathrm{V})$. A remarkable inter-

Table 9

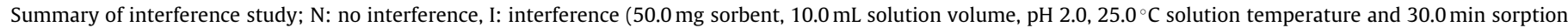
time, $n=3$ ).

\begin{tabular}{|c|c|c|c|c|c|c|}
\hline & \multicolumn{3}{|c|}{$10.0 \mu \mathrm{g} \mathrm{L}^{-1} \mathrm{~V}(\mathrm{~V})$} & \multicolumn{2}{|c|}{$100.0 \mu \mathrm{g} \mathrm{L}^{-1} \mathrm{~V}(\mathrm{~V})$} & \multirow{2}{*}{$\begin{array}{l}1000.0 \mu \mathrm{g} \mathrm{L}^{-1} \mathrm{~V}(\mathrm{~V}) \\
1000.0 \mu \mathrm{g} \mathrm{L}^{-1}\end{array}$} \\
\hline & $10.0 \mu \mathrm{g} \mathrm{L}^{-1}$ & $100.0 \mu \mathrm{g} \mathrm{L}^{-1}$ & $\overline{1000.0 \mu \mathrm{g} \mathrm{L}^{-1}}$ & $100.0 \mu \mathrm{g} \mathrm{L}^{-1}$ & $\overline{1000.0 \mu \mathrm{g} \mathrm{L}^{-1}}$ & \\
\hline $\mathrm{Te}(\mathrm{VI})$ & I & I & I & I & I & I \\
\hline $\mathrm{Se}(\mathrm{IV})$ & I & I & I & I & I & I \\
\hline $\mathrm{Se}(\mathrm{VI})$ & I & I & I & I & I & I \\
\hline $\mathrm{Sb}(\mathrm{III})$ & I & I & I & $\mathrm{N}$ & $\mathrm{N}$ & $\mathrm{N}$ \\
\hline $\mathrm{As}(\mathrm{III})$ & I & I & I & $\mathrm{N}$ & $\mathrm{N}$ & $\mathrm{N}$ \\
\hline $\mathrm{Mo}(\mathrm{VI})$ & I & I & I & $\mathrm{N}$ & $\mathrm{N}$ & $\mathrm{N}$ \\
\hline $\mathrm{Fe}(\mathrm{III})$ & I & I & I & I & I & I \\
\hline
\end{tabular}


Table 11

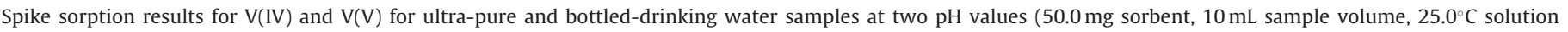
temperature and 30.0 min sorption time).

\begin{tabular}{|c|c|c|c|c|c|}
\hline & & \multicolumn{2}{|c|}{ Spike conc. $\left(\mu \mathrm{g} \mathrm{L}^{-1}\right)$} & \multirow[t]{2}{*}{ Conc. in the filtrates $\left(\mu \mathrm{g} \mathrm{L}^{-1}\right)$} & \multirow[t]{2}{*}{ \% Sorption } \\
\hline & & $\mathrm{V}(\mathrm{IV})$ & $\mathrm{V}(\mathrm{V})$ & & \\
\hline \multirow[t]{12}{*}{ Ultra pure water } & $\mathrm{pH}=2.0$ & 20.0 & - & $20.0 \pm 0.5$ & $\sim 0$ \\
\hline & & 200.0 & - & $200.0 \pm 1.5$ & $\sim 0$ \\
\hline & & - & 20.0 & $1.2 \pm 0.0$ & $93.9 \pm 0.4$ \\
\hline & & - & 200.0 & $9.2 \pm 0.1$ & $95.4 \pm 0.8$ \\
\hline & & 10.0 & 10.0 & $9.6 \pm 0.1$ & $104.0 \pm 0.7$ \\
\hline & & 100.0 & 100.0 & $108.4 \pm 2.8$ & $91.6 \pm 2.8$ \\
\hline & $\mathrm{pH}=3.0$ & 20.0 & - & $1.4 \pm 0.0$ & $93.1 \pm 0.5$ \\
\hline & & 200.0 & - & $9.4 \pm 0.0$ & $95.3 \pm 0.2$ \\
\hline & & - & 20.0 & $1.2 \pm 0.0$ & $93.8 \pm 0.7$ \\
\hline & & - & 200.0 & $10.4 \pm 0.1$ & $94.8 \pm 0.6$ \\
\hline & & 10.0 & 10.0 & $2.4 \pm 0.0$ & $88.1 \pm 1.0$ \\
\hline & & 100.0 & 100.0 & $11.6 \pm 0.1$ & $94.2 \pm 0.8$ \\
\hline \multirow[t]{12}{*}{ Bottled drinking water } & $\mathrm{pH}=2.0$ & 20.0 & - & $20.0 \pm 0.6$ & $\sim 0$ \\
\hline & & 200.0 & - & $200.0 \pm 1.7$ & $\sim 0$ \\
\hline & & - & 20.0 & $1.9 \pm 0.0$ & $90.6 \pm 0.3$ \\
\hline & & - & 200.0 & $6.0 \pm 0.0$ & $97.0 \pm 0.2$ \\
\hline & & 10.0 & 10.0 & $9.8 \pm 0.3$ & $102.0 \pm 0.8$ \\
\hline & & 100.0 & 100.0 & $102.4 \pm 1.9$ & $97.6 \pm 1.9$ \\
\hline & $\mathrm{pH}=3.0$ & 20.0 & - & $0.1 \pm 0.0$ & $99.6 \pm 0.2$ \\
\hline & & 200.0 & - & $10.4 \pm 0.1$ & $94.8 \pm 0.5$ \\
\hline & & - & 20.0 & $0.0 \pm 0.0$ & $100.3 \pm 0.7$ \\
\hline & & - & 200.0 & $5.8 \pm 0.0$ & $97.1 \pm 0.2$ \\
\hline & & 10.0 & 10.0 & $0.1 \pm 0.0$ & $99.6 \pm 0.2$ \\
\hline & & 100.0 & 100.0 & $10.8 \pm 0.1$ & $94.6 \pm 0.8$ \\
\hline
\end{tabular}

ference effect of all the ions tested (decrease in $>50 \%$ sorption) was seen for low $\left(10.0 \mu \mathrm{g} \mathrm{L}^{-1}\right)$ vanadate concentration. For higher (100.0 and $1000.0 \mu \mathrm{g} \mathrm{L}^{-1}$ ) vanadate concentrations, Te(VI), Se(IV), $\mathrm{Se}(\mathrm{VI})$, and $\mathrm{Fe}(\mathrm{III})$ still showed interferences whereas no interference was observed from $\mathrm{Sb}(\mathrm{III}), \mathrm{As}(\mathrm{III})$, and $\mathrm{Mo}(\mathrm{VI})$ ions. Moreover, no enhancement of $V(V)$ signal was observed.

\subsection{Method validation and real sample analysis}

The proposed method was validated through spike recovery tests and a certified reference material. Spiking was applied to four different types of water; namely, ultra pure, bottleddrinking, tap, and sea water at three different concentrations of $\mathrm{V}(\mathrm{V})$; namely $10.0 \mu \mathrm{gL}^{-1}, 100.0 \mu \mathrm{g} \mathrm{L}^{-1}$ and $1000.0 \mu \mathrm{g} \mathrm{L}^{-1}$. Spiked samples were subjected to the same sorption/elution cycles as previously. The results given in Table 10 show that the proposed methodology works efficiently for all types of waters at all concentrations (87-108\% recovery), except sea water spiked with $1000.0 \mu \mathrm{g} \mathrm{L}^{-1} \mathrm{~V}(\mathrm{~V})$ for which $73( \pm 3) \%$ recovery was obtained. In addition to the above-mentioned experiments which were carried out using a relatively high spike concentration of $1.0 \mathrm{mg} \mathrm{L}^{-1} \mathrm{~V}(\mathrm{~V})$ at $\mathrm{pH} 2.0$, spike recovery tests were repeated also with lower concentrations of both vanadium species at two different pHs; namely, $\mathrm{pH} 2.0$ for the sorption of only $\mathrm{V}(\mathrm{V})$ and $\mathrm{pH} 3.0$ for the sorption of total vanadium $(\mathrm{V}(\mathrm{IV})+\mathrm{V}(\mathrm{V}))$. The methodology was applied to ultra pure and bottled drinking water samples with the concentrations between $10.0 \mu \mathrm{g} \mathrm{L}^{-1}$ and $200.0 \mu \mathrm{g} \mathrm{L}^{-1}$. The results given in Table 11 demonstrate that, for both water types, at $\mathrm{pH}$ 2.0, the 3-APTES-functionalized silica sorbent shows quantitative sorption only to $\mathrm{V}(\mathrm{V})$ for all the concentrations tested while it displays no affinity to $\mathrm{V}(\mathrm{IV})$. On the other hand, $\mathrm{pH} 3.0$ must be employed if the total concentration of the vanadium species is to be determined. This characteristic behavior shows the speciation capability of the functionalized silica towards $V(I V)$ and $V(V)$ in waters.

In addition to the spike recovery tests, the accuracy of the proposed methodology was checked by analyzing a standard reference material (NIST, SRM 1643e) and a good agreement was found between the determined $35.47( \pm 0.57) \mu \mathrm{gL}^{-1}$ and the certified value $37.86( \pm 0.59) \mu \mathrm{g} \mathrm{L}^{-1}$.

\section{Conclusion}

3-APTES-functionalized silica sorbent has been shown to be an efficient material for the speciation of vanadium in waters. The optimum $\mathrm{pH}$ for the speciation of $\mathrm{V}(\mathrm{IV})$ and $\mathrm{V}(\mathrm{V})$ was found to be 2.0 where only $\mathrm{V}(\mathrm{V})$ is sorbed by the sorbent. A solution $\mathrm{pH}$ of 3.0 can be used if the total concentration of vanadium is to be determined. The concentration of V(IV) can then be calculated from the difference. This finding enhances a specific determination of total vanadium with an easy step like $\mathrm{pH}$ adjustment. Desorption from the sorbent was realized with $0.5 \mathrm{~mol} \mathrm{~L}^{-1}$ thiourea in $0.2 \mathrm{~mol} \mathrm{~L}^{-1}$ $\mathrm{HCl}$.

Among the tested isotherm models, Langmuir model appeared to be the most appropriate within the whole concentration range with high correlation coefficient which indicates a monolayer sorption process. In addition, sorption of $\mathrm{V}(\mathrm{V})$ by 3-APTESfunctionalized silica decreased with the increase in solution temperature and this exothermic behavior is associated with a decrease in system entropy.

An interference effect is observed for Te(IV), Se(IV), Se(VI), and $\mathrm{Fe}(\mathrm{III})$ ions through decreasing the percent sorption of $\mathrm{V}(\mathrm{V})$. Additionally, $\mathrm{Mo}(\mathrm{VI}), \mathrm{Sb}(\mathrm{III})$ and $\mathrm{Se}(\mathrm{VI})$ were almost completely removed from the solutions at all tested concentrations. This promising sorption behavior of the novel sorbent towards the above-mentioned oxyanions has also boosted further studies in the authors' laboratory for selective determination of these ions.

The validity of the method was checked both with spike recovery experiments with four different types of water, ultra pure, bottleddrinking, tap, and sea water, at different $\mathrm{V}(\mathrm{V})$ concentrations and a standard reference material (NIST, SRM 1643e). The results demonstrated the efficiency of the method. The proposed methodology has been shown to be applicable for the separate sorption of $\mathrm{V}(\mathrm{V})$ in the absence/presence of V(IV) and for the sorption of both V(IV) and $\mathrm{V}(\mathrm{V})$ in waters. The amount of $\mathrm{V}(\mathrm{IV})$ can then be determined from the difference. 


\section{Acknowledgements}

The authors would like to thank the Center of Material Research for the facilities SEM, TGA, BET-N $\mathrm{N}_{2}$, and the Environmental Research Center for ICP-MS measurements, at İzmir Institute of Technology. Aslı Erdem would like to thank Ezel Boyacı, Arzu Erdem and Onur Yayayürük for their valuable contributions to this study.

\section{References}

[1] S.E. Bailey, T.J. Olin, R.M. Bricka, D.D. Adrian, A review of potentially low-cost sorbents for heavy metals, Water Res. 33 (1999) 2469-2479.

[2] V.K. Gupta, I. Ali, Utilisation of bagasse fly ash (a sugar industry waste) for the removal of copper and zinc from wastewater, Sep. Purif. Technol. 18 (2000) 131-140.

[3] F.W. Fifield, P.J. Haines, Environmental Analytical Chemistry, Chapman and Hall, London, 1995.

[4] N.K. Lazaridis, M. Jekel, A.I. Zouboulis, Removal of $\mathrm{Cr}(\mathrm{VI}), \mathrm{Mo}(\mathrm{VI})$ and V(V) ions from single metal solutions by (i) sorption, or (ii) nano-filtration, Sep. Sci. Technol. 38 (2003) 2201-2219.

[5] K. Pyrzynska, T. Wierzbicki, Determination of vanadium species in environmental samples, Talanta 64 (2004) 823-829.

[6] R.R. Moskalyk, A.M. Alfantazi, Processing of vanadium: a review, Miner. Eng. 16 (2003) 793-805.

[7] A. Naeem, P. Westerhoff, S. Mustafa, Vanadium removal by metal (hydr)oxide adsorbents, Water Res. 41 (2007) 1596-1602.

[8] C.P. Peacock, D.M. Sherman, Vanadium(V) adsorption onto goethite $(\alpha-\mathrm{FeOOH})$ at $\mathrm{pH}$ 1.5-12: a surface complexation model based on ab initio molecular geometries and EXAFS spectroscopy, Geochim. Cosmochim. Acta 68 (2004) 1723-1733.

[9] K. Pyrzynska, Selected problems in speciation analysis of vanadium in water samples, Chem. Anal. (Warsaw, Pol.) 51 (2006) 339-350.

[10] A.M. Evangelou, Vanadium in cancer treatment, Crit. Rev. Oncol. Hematol. 42 (2002) 249-265.

[11] D. Crans, Chemistry and insulin-like properties of vanadium(IV) and vanadium(V) compounds ${ }^{1}$, J. Inorg. Biochem. 80 (2000) 123-131.

[12] M. Colina, P.H.E. Gardiner, Z. Rivas, F. Troncone, Determination of vanadium species in sediment, mussel and fish muscle tissue samples by liquid chromatography-inductively coupled plasma-mass spectrometry, Anal. Chim. Acta 538 (2005) 107-115.

[13] K.S. Kumar, S.H. Kang, K. Suvardhan, K. Kiran, Facile and sensitive spectrophotometric determination of vanadium in various samples, Environ. Toxicol. Pharmacol. 24 (2007) 37-44.

[14] N. Teshima, M. Kuno, M. Ueda, H. Ueda, S. Ohno, T. Sakai, Automated stoppedin-dual-loop flow analysis system for catalytic determination of vanadium in drinking water, Talanta 79 (2009) 517-522.

[15] K. Umetsu, I. Itabashik, E. Satoh, T. Kawashima, Effect of ligands on the redox reaction of metal ions and the of a ligand buffer for improving the end-point detection in the potentiometric titration of vanadium(V) with iron(II), Anal. Sci. 7 (1991) 115-118

[16] A. Nair, J. Christine, 2-Hydroxy-4-n-propoxy-5-bromoacetophenone oxime as an analytical reagent for gravimetric determination of V(V), E-J. Chem. 6(2009) 303-307.

[17] A. Bhatnagar, A.K. Minocha, D. Pudasainee, H.K. Chung, S.H. Kim, H.S. Kim, G. Lee, B. Min, B.H. Jeon, Vanadium removal from water by waste metal sludge and cement immobilization, Chem. Eng. J. 144 (2008) 197-204.

[18] S. Ueoka, J. Furukawa, T.M. Nakanishi, Multi-elemental profile patterns during the life cycle stage of the soybean, Part 2. Determination of transition elements, V, Cr, Mn, Fe and Zn, J. Radioanal. Nucl. Chem. 249 (2001) 475-480.

[19] L. Minelli, E. Veschetti, S. Giammanco, G. Mancini, M. Ottaviani, Vanadium in Italian waters: monitoring and speciation of V(IV) and V(V), Microchem. J. 67 (2000) 83-90.

[20] Y. Wu, Z. Jiang, B. Hu, Speciation of vanadium in water with quinine modified resin micro-column separation/preconcentration and their determination by fluorination assisted electrothermal vaporization (FETV)-inductively coupled plasma optical emission spectrometry (ICP-OES), Talanta 67 (2005) 854-861.

[21] F. Aureli, S. Ciardullo, M. Pagano, A. Raggi, F. Cubadda, Speciation of vanadium(IV) and (V) in mineral water by anion exchange liquid chromatography-inductively coupled plasma mass spectrometry after EDTA complexation, J. Anal. At. Spectrom. 23 (2008) 1009-1016.

[22] H. Filik, K.I. Berker, N. Balkis, R. Apak, Simultaneous preconcentration of vanadium(V/IV) species with palmitoyl quinolin-8-ol bonded to amberlite XAD 2 and their separate spectrophotometric determination with 4-(2-pyridylazo)resorcinol using CDTA as masking agent, Anal. Chim. Acta 518 (2004) 173-179.

[23] K. Pyrzynska, Recent developments in spectrophotometric methods for determination of vanadium, Microchim. Acta 149 (2005) 159-164.
[24] S. Moyano, G. Polla, P. Smichowski, J.A. Gasquez, L.D. Martinez, On-line preconcentration and determination of vanadium in tap and river water samples by flow injection-inductively coupled plasma-optical emission spectrometry (FI-ICP-OES), J. Anal. At. Spectrom. 21 (2006) 422-426.

[25] P.H. Pacheco, R.A. Olsina, P. Smichowski, L.D. Martinez, On-line preconcentration and speciation analysis of inorganic vanadium in urine using L-methionine immobilised on controlled pore glass, Talanta 74 (2008) 593-598.

[26] K. Pyrzynska, T. Wierzbicki, Preconcentration and separation of vanadium on Amberlite IRA-904 resin functionalized with porphyrin ligands, Anal. Chim. Acta 540 (2005) 91-94.

[27] Z. Fan, B. Hu, Z. Jiang, Speciation analysis of vanadium in natural water samples by electrothermal vaporization inductively coupled plasma optical emission spectrometry after separation/preconcentration with thenoyltrifluoroacetone immobilized on microcrystalline naphthalene, Spectrochim. Acta Part B 60 (2005) 65-71.

[28] I. Nukatsuka, Y. Shimizu, K. Ohzeki, Determination of vanadium(IV) and vanadium(V) by electrothermal atomic-absorption spectrometry following selective solid-phase extraction and the study on the change in the oxidation state of vanadium species in sea water during the sample storage, Anal. Sci. 18 (2002) 1009-1014.

[29] K. Okamura, M. Sugiyama, H. Obata, M. Maruo, E. Nakayama, H. Karatani, Automated determination of vanadium(IV) and (V) in natural waters based on chelating resin separation and catalytic detection with Bindschedler's green leuco base, Anal. Chim. Acta 443 (2001) 143-151.

[30] C. Xiong, Y. Qin, B. Hu, On-line separation/preconcentration of $V(I V) / V(V)$ in environmental water samples with CTAB-modified alkyl silica microcolumn and their determination by inductively coupled plasma-optical emission spectrometry, J. Hazard. Mater. 178 (2010) 164-170.

[31] Z.L. Chen, G. Owens, Trends in speciation analysis of vanadium in environmental samples and biological fluids-a review, Anal. Chim. Acta 607 (2008) $1-14$.

[32] X.D. Liu, S. Tokura, M. Haruki, N. Nishi, N. Sakairi, Surface modification of nonporous glass beads with chitosan and their adsorption property for transition metal ions, Carbohyd. Polym. 49 (2002) 103-108.

[33] L. Huang, J.C. Wu, S. Kawi, $\mathrm{Rh}_{4}(\mathrm{CO})_{12}$-derived functionalized MCM-41-tethered rhodium complexes: preparation, characterization and catalysis for cyclohexene hydroformylation, J. Mol. Catal. A: Chem. 206 (2003) 371-387.

[34] K.Y. Ho, G. McKay, K.L. Yeung, Selective adsorbents from ordered mesoporous silica, Langmuir 19 (2003) 3019-3024.

[35] M. Puanngam, F. Unob, Preparation and use of chemically modified MCM-41 and silica gel as selective adsorbents for $\mathrm{Hg}$ (II) ions, J. Hazard. Mater. 154 (2008) 578-587.

[36] C. Ekinci, Ü. Köklü, Determination of vanadium, manganese, silver and lead by graphite furnace atomic-absorption spectrometry after preconcentration on silica-gel modified with 3-aminopropyltriethoxysilane, Spectrochim Acta Part B 55 (2000) 1491-1495.

[37] G. Limousin, J.P. Gaudet, L. Charlet, S. Szenknect, V. Barthes, M. Krimissa, Sorption isotherms: a review on physical bases, modeling and measurement, Appl. Geochem. 22 (2007) 249-275.

[38] L. Qi, Z. Xu, Lead sorption from aqueous solutions on chitosan nanoparticles, Colloid Surf. A: Physiochem. Eng. Asp. 251 (2004) 183-190.

[39] S. Gueu, B. Yao, K. Adouby, G. Ado, Kinetics and thermodynamics study of lead adsorption on to activated carbons from coconut and seed hull of the palm tree, Int. J. Environ. Sci. Technol. 4 (2007) 11-17.

[40] C. Mahamadi, R. Chapeyama, Divalent metal ion removal from aqueous solution by acid-treated and garlic-treated Canna indica roots, J. Appl. Sci. Environ. Manage. 15 (1) (2011) 97-103.

[41] R.J. Umpleby, S.C. Baxter, M. Bode, J.K. Berch Jr., R.N. Shaha, K.D. Shimizu, Application of the Freundlich adsorption isotherm in the characterization of molecularly imprinted polymers, Anal. Chim. Acta 435 (2001) 35-42.

[42] S.I.H. Taqvi, S.M. Hasany, M.I. Bhanger, Sorption profile of Cd(II) ions onto beach sand from aqueous solutions, J. Hazard. Mater. 141 (2007) 37-44.

[43] D. Kavithaand, C. Namasivayam, Recycling coir pith, an agricultural solid waste, for the removal of procion orange from wastewater, Dyes Pigment 74 (2007) 237-248.

[44] A. Şeker, T. Shahwan, A.E. Eroğlu, S. Yılmaz, Z. Demirel, M.C. Dalay, Equilibrium, thermodynamic and kinetic studies for the biosorption of aqueous lead(II), cadmium(II) and nickel(II) ions on Spirulina platensis, J. Hazard. Mater. 154 (2008) 973-980.

[45] M. Yersel, A. Erdem, A.E. Eroğlu, T. Shahwan, Separation of trace antimony and arsenic prior to hydride generation atomic absorption spectrometric determination, Anal. Chim. Acta 534 (2005) 293-300.

[46] P. Atkins, J. de Paula, Atkins' Physical Chemistry, Oxford University Press, New York, 2006

[47] K. Albert, R. Brindle, J. Schmid, B. Buszewski, E. Bayer, CP/MAS NMR Investigations of silica gel surfaces modified with aminopropylsilane, Chromatographia 38 (5/6) (1994) 283-290.

[48] T. Takei, K. Mukasa, M. Kofuji, M. Fuji, T. Watanabe, M. Chikazawa, T. Kanazawa, Changes in density and surface tension of water in silica pores, Colloid Polym. Sci. 278 (2000) 475-480. 